\title{
Pelagic Larval Duration and Settlement Size of Apogonidae, Labridae, Scaridae, and Tripterygiidae Species in a Coral Lagoon of Okinawa Island, Southern Japan ${ }^{1}$
}

\author{
Taiki Ishibara ${ }^{2}$ and Katsunori Tachibara ${ }^{3,4}$
}

\begin{abstract}
Pelagic larval duration and settlement sizes in species of Apogonidae, Labridae, Scaridae, and Tripterygiidae in a coral lagoon in southern Japan were examined. Sampling was conducted monthly from July 2004 to June 2005 in the coral lagoon and channel of the Oh-do Beach on Okinawa Island, Japan. Pelagic larval duration was estimated by the number of otolith increments. Mean standard length at settlement of apogonids ranged from 7.7 to $13.9 \mathrm{~mm}$, and mean pelagic larval duration ranged from 14.0 to 30.6 days (14 species, 418 individuals). In labrids, mean standard length at settlement and pelagic larval duration varied greatly (mean standard length: $5.4-11.0 \mathrm{~mm}$; pelagic larval duration: 18-57 days, four species, four individuals). Scarids showed consistent mean standard length at settlement and pelagic larval duration (mean standard length: 7.1-7.6 mm; pelagic larval duration: 29-42 days, five species, 25 individuals). In tripterygiids, pelagic larval duration was more consistent (range: 18-29 days, mean: $22.2 \pm 2.1$ days), but mean standard length at settlement ranged from 7.8 to $10.3 \mathrm{~mm}$ (six species, 32 individuals). These results suggest that the pelagic larval duration of Apogonidae and Tripterygiidae (nonpelagic egg spawning) is shorter than that of Labridae and Scaridae (pelagic egg spawning), and the dispersal strategy of labrids and scarids may include wider dispersal than that of apogonids and tripterygiids.
\end{abstract}

The Life History of most coral reef fishes includes a pelagic larval phase (Leis 1991). Hatched larvae inhabit open water and grow to become pelagic larvae. These pelagic lar-

${ }^{1}$ This study was partially supported by the 21 st Century Center of Excellence (COE) Program of the University of the Ryukyus. Manusucript accepted 1 May 2010.

${ }^{2}$ Graduate School of Engineering and Science, University of the Ryukyus, 1 Senbaru, Nishihara-cho, Nakagami-gun, Okinawa 903-0213, Japan (e-mail: pipefish@mail.goo.ne.jp).

${ }^{3}$ Laboratory of Fisheries Biology and Coral Reef Studies, Faculty of Science, University of the Ryukyus, 1 Senbaru, Nishihara-cho, Nakagami-gun, Okinawa 903-0213, Japan.

${ }^{4}$ Corresponding author (e-mail: ktachiha@sci.uryukyu.ac.jp).

Pacific Science (2011), vol. 65, no. 1:87-93

doi: 10.2984/65.1.087

(C) 2011 by University of Hawai'i Press

All rights reserved vae search for suitable benthic habitats on coral reefs using visual, acoustic, chemical, or other senses before settlement (Montgomery et al. 2001). The length of the pelagic larval duration influences the survival and dispersal of coral reef fishes (Wellington and Victor 1989, Doherty 1991, Cowen 2002).

Pelagic larval duration and size at settlement are basic life history characters of coral reef fishes and are important in understanding coral reef ecosystems. Pelagic larval duration can be determined by examining otoliths of fish larvae that reach settlement sites. Pannella (1971) showed that microincrements of otoliths form daily. Many studies have shown that increments in otoliths form daily in both temperate (Kingsford and Milicich 1987) and tropical (Thresher et al. 1989, Moreno and Morales-Nin 2003) reef fishes. Researchers have estimated the pelagic larval durations of some coral reef fishes by the number of otolith increments of larvae and juveniles just before or after settlement (Brothers et al. 1983, 
Wilson and McCormick 1997, 1999, Victor and Wellington 2000). However, information about the settlement size and pelagic larval duration of coral reef fishes is still scarce.

Okinawa Island, in the middle of the Ryukyu Archipelago, lies on the boundary of the East China Sea and the western Pacific Ocean in the subtropical Kuroshio Current region. The coral reefs surrounding Okinawa Island are well developed, and many coral reef and some temperate fish species inhabit the area (Nakabo 2002). Apogonids, labrids, scarids, and tripterygiids are dominant in the coral lagoon of Okinawa Island. These four families have different egg characters. Apogonids and tripterygiids spawn demersal eggs, and labrids and scarids spawn pelagic eggs (Shiogaki and Dotsu 1973a,b, Richards and Lindeman 1987, Ikeda and Mito 1988). This difference may influence the pelagic larval duration and settlement size of larvae and juveniles. In this study, we estimated settlement sizes and pelagic larval duration of species in these four families caught in the coral lagoon of Okinawa Island and discuss the dispersal strategy of these four families.

\section{MATERIALS AND METHODS}

This study was conducted on Oh-do Beach $\left(26^{\circ} 5^{\prime} \mathrm{N}, 127^{\circ} 42^{\prime} \mathrm{E}\right)$, Okinawa Island, southern Japan (Figure 1). The Oh-do Beach lagoon lies on the southern tip of the island and comprises approximately $120,000 \mathrm{~m}^{2}$, with a maximum water depth of $3.5 \mathrm{~m}$ and an outer-reef depth of $35 \mathrm{~m}$ at low tide (Figure 1). Sampling was conducted in the channel ( $7 \mathrm{~m}$ wide, $2 \mathrm{~m}$ deep at low tide) and lagoon of Oh-do Beach. From high tide to low tide, a strong current flows from the inner to outer reef in the channel.

Larvae were collected monthly from July 2004 to June 2005, using a larval net and a small seine net. The $4 \mathrm{~m}$ long larval net had a square mouth $\left(1 \mathrm{~m}^{2}\right)$ and was constructed of $1.5 \mathrm{~mm}$ mesh (first $3 \mathrm{~m}$ from the mouth) and $1.0 \mathrm{~mm}$ mesh (last $1 \mathrm{~m}$ ), with two buoys attached to the mouth and one to the cod end. The small seine net was $4 \mathrm{~m}$ wide and 1 $\mathrm{m}$ high and constructed of $1.0 \mathrm{~mm}$ mesh. Larvae carried by the strong current in the

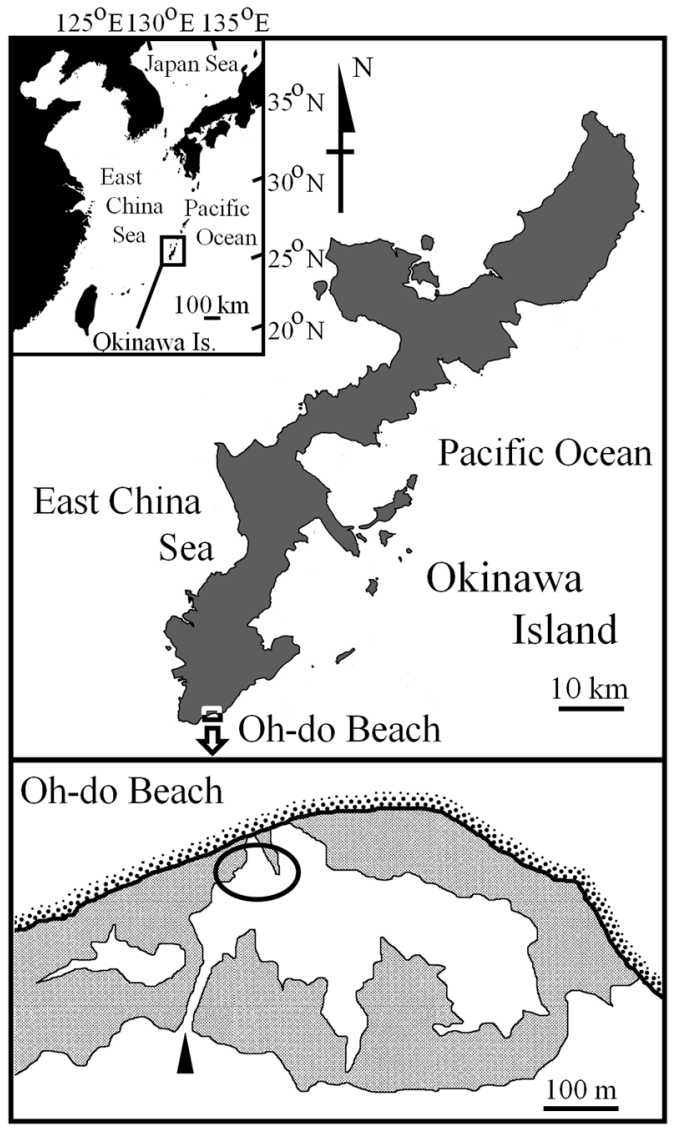

Figure 1. Location of Okinawa Island and Oh-do Beach. Circle shows the beach seine sampling site. Shading shows areas exposed at low tide. The triangle indicates Oh-do Beach channel.

channel were collected with the larval net deployed between high and low tide on new- or full-moon nights, with a mean deployment time of $178 \pm 40$ min (mean \pm SD). Strong tidal currents were absent in the lagoon, and larvae were collected by small seine netting on new- or full-moon nights. The substrata at the sampling points in the lagoon were sea-grass beds and small reef patches on coral sand. The total seine haul distance each month was $100 \mathrm{~m}$.

The collected fishes were preserved in $99 \%$ alcohol as soon as possible. In the laboratory, they were sorted to the lowest taxonomic level, and the standard length (SL) 
was measured. The otoliths were removed and embedded in clear nail varnish on microscope slides, and the otolith increments were counted under a microscope.

Pelagic larval duration was estimated by counting the number of otolith increments of "settlement-stage" larvae. Settlementstage larvae dwelling in the shallow coral lagoon have translucent bodies, poor pigmentation, and almost complete fins. Generally, such larvae settle within a few days. These larvae were identifiable based on their morphology, pigmentation pattern, and meristic characters (Okiyama 1998).

In many families, otolith increments form daily, and the number of increments corresponds to the age in days of larvae and juveniles (Pomacentridae: Thresher et al. 1989, Holocentridae: Tyler et al. 1993, Mullidae and Microdesmidae: McCormick and Makey 1997, Atherinidae: Moreno and Morales-Nin 2003). Victor (1982) reported that otolith increments of labrid species begin to form 1 to 2 days after fertilization, and Raventós and Macpherson (2001) reported that they begin to form from the day of hatching. In this study, otolith increments were assumed to form daily from the day of hatching. Right sagitta was used for labrids, scarids, and tripterygiids, and right lapillus was used for apogonids because the sagitta was too thick to count increments. For these specimens, the total increment count was assumed to equal the time spent in the plankton, which is close to the pelagic larval duration of the individual.

We identified settlement-stage larvae to species or genus level whenever possible based on Okiyama (1998). Okiyama (1998) proposed a range of useful characters for identifying apogonid and labrid larvae and juveniles. Key characters for species-level identification of apogonid species are as follows: body shape, shape and number of posterior preopercular spines, pigment patterns on the head, number of longitudinal melanophore stripes, and dorsal and ventral surface pigments of the caudal peduncle; key characters of labrid species: pigment patterns on the head, dorsal fin base, and anal fin base; number of rays on each fin; and body shape.
Okiyama (1998) also described detailed pigment patterns and body shapes in larvae and juveniles of scarid larvae. Presence or absence of melanophores arranged along the caudal fin rays and pigment patterns of dorsal and ventral surfaces of the caudal peduncle were useful for identification of settlement-stage Scarus species. We used these characters to identify five Scarus species. For tripterygiid species, number of fin rays varies between many species (Nakabo 2002), and we observed taxon-specific variations in pigment patterns on the nape, top of the head, anal fin base, and dorsal and ventral surfaces of the caudal peduncle.

RESULTS

\section{Apogonidae}

Fourteen taxa (12 Apogoninae species, two Pseudaminae species) of apogonid settlement-stage larvae were caught. Of the 418 individuals examined for otolith increments, mean standard length (SL) for settlement-stage larvae of apogonids was $9.9 \pm 0.1 \mathrm{~mm}$ (mean $\pm \mathrm{SD})$. But there was variation between species within apogonids (Figure 2). Apogonichthys waikiki displayed the smallest settlement size $(7.7 \pm 0.2 \mathrm{~mm}$ SL, $n=14$ ), and Apogon novemfasciatus had the largest settlement size $(13.9 \pm 0.4 \mathrm{~mm}$ SL, $n=6)$. The average pelagic larval duration for apogonids was $19.9 \pm 0.2$ days $(n=418$ [Figure 2]). Apogon sp. 3 and Gymnapogon sp. 1 showed the shortest pelagic larval duration $(14.3 \pm 0.7$ days, $n=3 ; 14.0$ days, $n=1$, respectively), and Foa brachygramma had the longest pelagic larval duration $(30.6 \pm 0.7$ days, $n=33)$.

\section{Labridae}

Four taxa (one Thalassoma species, one Pseudocheilinus species, two Xyrichtys species) of settlement-stage labrid larvae were caught, and the otolith increments of five individuals were counted. The relationship between pelagic larval duration and settlement size varied widely among labrid species (Figure 3). The SL of settlement-stage larvae were 


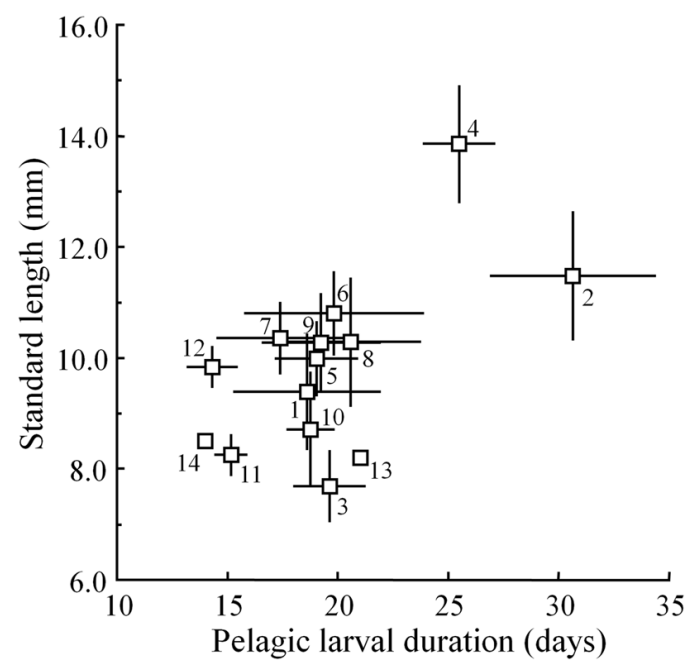

Figure 2. Relationship between mean standard length and mean pelagic larval duration of Apogonidae species. Bars show the standard deviation. Specimens were collected monthly from July 2004 to June 2005 in the lagoon and channel of Oh-do Beach on Okinawa Island. Numbers indicate each species: 1, Cheilodipterus quinquelineatus $(n=135) ; 2$, Foa brachygramma $(n=33) ; 3$, Apogonichtbys waikiki $(n=14) ; 4$, Apogon novemfasciatus $(n=6) ; 5$, Apogon properuptus $(n=39) ; 6$, Apogon doederleini $(n=6) ; 7$, Apogon cookii $(n=16) ; 8$, Apogon timorensis $(n=21) ; 9$, Apogon nubilus $(n=124) ; 10$, Apogon sp. $1(n=13) ; 11$, Apogon sp. $2(n=6) ; 12$, Apogon sp. $3(n=3) ; 13$, Gymnapogon japonicas $(n=1) ; 14$, Gymnapogon sp. $1(n=1)$.

5.3 and $5.5 \mathrm{~mm}$ for Pseudocheilinus sp. 1, 6.9 $\mathrm{mm}$ for Thalassoma sp. 1, $10.0 \mathrm{~mm}$ for $X y$ richtys sp. 1, and $11.0 \mathrm{~mm}$ for Xyrichtys sp. 2. The estimated pelagic larval durations were 18 and 19 days for Pseudocheilinus sp. 1, 45 days for Thalassoma sp. 1, 55 days for Xyrichtys sp. 1, and 40 days for Xyrichtys sp. 2 (Figure 3).

\section{Scaridae}

Five taxa (five Scarus species) of settlementstage larvae were identified among the 25 individuals for which otolith increments were counted. Among all Scarus species, mean SL of settlement-stage larvae ranged from 7.1 to $7.6 \mathrm{~mm}$ (Figure 3). The mean pelagic larval durations of all Scarus species ranged from 29.0 to 41.8 days. These results suggest that variation was limited in pelagic larval dura-

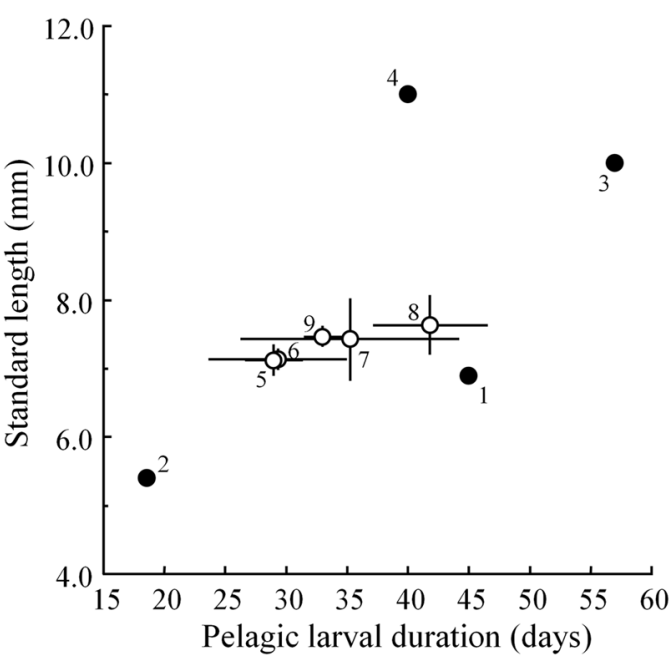

Figure 3. Relationship between mean standard length and mean pelagic larval duration of Labridae and Scaridae species. Solid circles show labrids, and, open circles show scarids. Bars show the standard deviation. Specimens were collected monthly from July 2004 to June 2005 in the lagoon and channel of Oh-do Beach on Okinawa Island. Numbers indicate each species: 1, Thalassoma sp. $1(n=1) ; 2$, Pseudocheilinus sp. $1(n=2) ; 3$, Xyrichtys sp. $1(n=1) ; 4$, Xyrichtys sp. $2(n=1) ; 5$, Scarus sp. $1(n=9) ; 6$, Scarus sp. $2(n=3) ; 7$, Scarus sp. 3 $(n=4) ; 8$, Scarus sp. $4(n=6) ; 9$, Scarus sp. $5(n=3)$.

tion, and settlement size of these Scarus species was relatively constant (pelagic larval duration: $33.8 \pm 7.0$ days, SL: $7.3 \pm 0.4 \mathrm{~mm}$ ).

\section{Tripterygiidae}

Six taxa (two Enneapterygius species, four species of unknown genus) of settlement-stage tripterygiid larvae were caught. Otolith increments were counted in 32 individuals. The pelagic larval durations of these tripterygiid species were relatively consistent (range: 1829 days, mean: $22.2 \pm 2.1$ days), but there was variation in body size among species (Figure 4). Enneapterygius tutuilae, Enneapterygius minutes, and Tripterygiidae sp. 1 had small settlement sizes $(8.1 \pm 0.6 \mathrm{~mm}, n=$ 26), whereas Tripterygiidae sp. 2, 3, and 4 had larger settlement sizes $(10.1 \pm 0.6 \mathrm{~mm}$, $n=6$ ). 


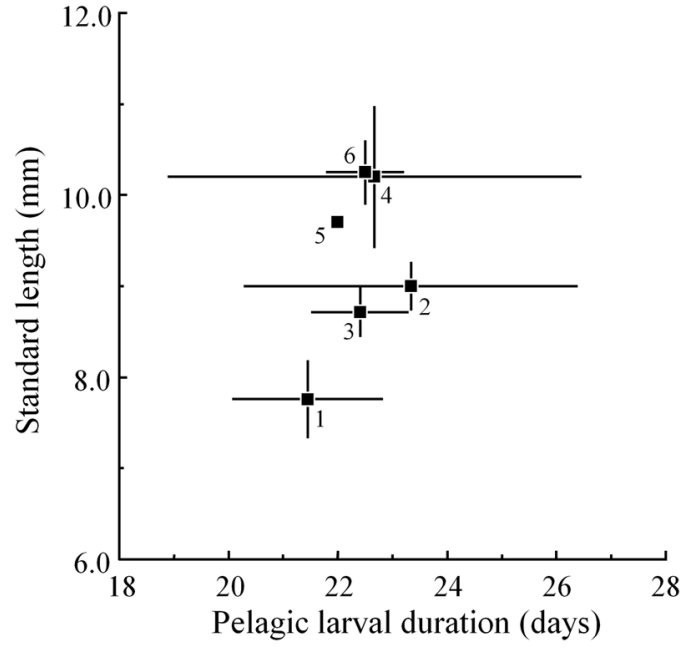

Figure 4. Relationship between mean standard length and mean pelagic larval duration of Tripterygiidae species. Bars show the standard deviation. Specimens were collected monthly from July 2004 to June 2005 in the lagoon and channel of Oh-do Beach on Okinawa Island. Numbers indicate each species: 1, Enneapterygius minutes $(n=18) ; 2$, Enneapterygius tutuilae $(n=3)$; 3, Tripterygiidae sp. $1(n=5)$; 4, Tripterygiidae sp. $2(n=3) ; 5$, Tripterygiidae sp. $3(n=1) ; 6$, Tripterygiidae sp. $4(n=2)$.

\section{DISCUSSION}

We identified settlement-stage larvae to the species or genus level whenever possible, and some useful characters were observed for identification to species or genus level of apogonid, labrid, scarid, and tripterygiid settlement-stage larvae, but most of the scarids and tripterygiids were not identifiable to species, and more work is required to improve taxonomic resolution.

In this study, the pelagic larval durations and settlement sizes of apogonids were very close to those of apogonids on the Great Barrier Reef (Brothers et al. 1983) and in the Mediterranean (Raventós and Macpherson 2001). However, the pelagic larval durations of tripterygiids were longer and the settlement sizes were smaller than those of Mediterranean tripterygiids (Raventós and Macpherson 2001). In labrids, the size at settlement and pelagic larval duration varied widely among species in our study. Wide variations were also reported in Great Barrier Reef (Brothers et al. 1983, Wilson and McCormick 1999) and Mediterranean (Raventós and Macpherson 2001) labrids, and the breadth of variation was almost the same as in our study. In scarids, pelagic larval duration and settlement size were more consistent among species in our study. On the Great Barrier Reef, pelagic larval duration of scarids was longer and the sizes at settlement were larger (Brothers et al. 1983) than results in our study. These differences suggest that the relationship between size at settlement and pelagic larval duration differs regionally. Raventós and Macpherson (2001) suggested seasonal and regional variation of pelagic larval duration in Mediterranean littoral fishes. However, information about pelagic larval durations and settlement sizes in other regions and species are scarce, and more research is needed.

In our study, variation in settlement sizes and pelagic larval duration were observed within some taxa. Ambient water temperature generally affects larval growth (Raventós and Macpherson 2001). Furthermore, ecological conditions of settlement substrate likely affect settlement size and pelagic larval duration. Raventós and Macpherson (2005) suggested that predation pressure influenced the settlement size of labrid larvae. They suggested that the predation pressure of larvae settling in complex substrata with many hiding places is lower than that on larvae settling on bare substrata, such as a sand bottom. Larvae with less predation pressure can settle with a shorter pelagic larval duration and smaller body length. Previous studies suggested that pelagic juveniles of Thalassoma (Labridae) and Chlorurus (Scaridae) species can delay settlement if they do not detect a suitable settlement ground (Victor 1986, Cowen 1991, Wellington and Victor 1992). Few data on settlement-stage larvae of these fishes are available, and more studies are required.

Leis et al. (1998, 2003) suggested that larvae of some fish complete their larval life in atoll lagoons; these fish may be called "completers." Foa sp., C. quinquelineatus, some Apogon species, and some tripterygiids could be considered "completers," but labrids and 
scarids are not. Leis et al. (1998, 2003) found that most "completers" are nonpelagic egg spawners. Apogonids and tripterygiids are demersal egg spawners, with the newly hatched larvae having functional fins and eyes, whereas labrids and scarids are pelagic egg spawners, with newly hatched larvae lacking functional fins, mouth, or eyes (Shiogaki and Dotsu 1973a,b, Richards and Lindeman 1987, Ikeda and Mito 1988). Consequently, the swimming ability of newly hatched apogonid and tripterygiid larvae is presumed to be higher than that of labrid and scarid species. In our study, the pelagic larval durations of apogonids and tripterygiids were shorter than those of most labrids and scarids. Foa brachygramma had the longest pelagic larval duration among the apogonids in our study, and Foa species have been suggested to be "completers" (Leis et al. 1998, 2003). The pelagic larval durations of tripterygiids were almost the same as those of apogonids. These findings suggest that most apogonids and tripterygiids may be "completers." However, they may not complete their larval life in Okinawa Island lagoons, because these lagoons are smaller and shallower than those of atolls. Rather, apogonids and tripterygiids larvae may remain around the natal lagoon of Okinawa Island. On the other hand, newly hatched labrid and scarid larvae are poorly developed, making them more likely to be carried away from their natal island. Therefore, the dispersal strategies of scarids and labrids may involve wider dispersal than that of apogonids and tripterygiids. Because a wide dispersal strategy risks the loss of suitable settlement substrata, the long pelagic larval duration of most labrid and scarid larvae may compensate for the risk.

\section{ACKNOWLEDGMENTS}

We are grateful to Emeritus Professor S. Shokita and Associate Professor T. Yoshino (Faculty of Sciences, University of the Ryukyus [FSUR]) for their support. We thank W. Noda and Y. Mizuno for informative discussions, as well as FSUR Laboratory personnel and members of the University of the Ryukyus Diving Club. We also thank Assis- tant Professor J. D. Reimer (FSUR) for critical comments on an early draft of the manuscript and help with English.

\section{Literature Cited}

Brothers, E. B., D. McB. Williams, and P. F. Sale. 1983. Length of larval life in twelve families at "One Tree Lagoon," Great Barrier Reef, Australia. Mar. Biol. (Berl.) 76:319-324.

Cowen, R. K. 1991. Variation in the planktonic larval duration of the temperate wrasse Semicossyphus pulcher. Mar. Ecol. Prog. Ser. 69:9-15.

. 2002. Larval dispersal and retention and consequences for population connectivity. Pages 149-170 in P. F. Sale, ed. Coral reef fishes, dynamics, and diversity in a complex ecosystem. Academic Press, New York.

Doherty, P. J. 1991. Spatial and temporal patterns in recruitment. Pages 261-293 in P. F. Sale, ed. The ecology of fishes on coral reefs. Academic Press, New York.

Ikeda, T., and S. Mito. 1988. Fish eggs and larvae with pictorial key to species. Pages 999-1083 in M. Okiyama, ed. An atlas of the early stage fishes in Japan. Tokai University Press, Tokyo.

Kingsford, M. J., and M. J. Milicich. 1987. Presettlement phase of Parika scaber (Pisces: Monacanthidae): A temperate reef fish. Mar. Ecol. Prog. Ser. 36:65-79.

Leis, J. M. 1991. The pelagic stage of reef fishes: The larval biology of coral reef fishes. Pages 183-230 in P. F. Sale, ed. The ecology of fishes on coral reefs. Academic Press, New York.

Leis, J. M., T. Trnski, P. J. Doherty, and V. Dufour. 1998. Replenishment of fish populations in the enclosed lagoon of Taiaro Atoll (Tuamotu Archipelago, French Polynesia): Evidence from eggs and larvae. Coral Reefs 17:1-8.

Leis, J. M., T. Trnski, V. Dufour, M. Harmelin-Vivien, J.-P. Renon, and R. Galzin. 2003. Local completion of the pelagic larval stage of coastal fishes in coral-reef lagoons of the Society and Tuamotu islands. Coral Reefs 22:271-290. 
McCormick, M. I., and L. J. Makey. 1997. Post-settlement transition in coral reef fishes: Overlooked complexity in niche shifts. Mar. Ecol. Prog. Ser. 153:247-257.

Montgomery, J. C., N. Tolimieri, and O. S. Haine. 2001. Active habitat selection by pre-settlement reef fishes. Fish and Fish. 2:261-277.

Moreno, T., and B. Morales-Nin. 2003. Age determination and validation on otoliths of the sand-smelt Atherina presbyter $(\mathrm{Cu}-$ vier, 1829) (Pisces: Atherinidae) from the central-East Atlantic. Fish. Res. (Amst.) 62:77-87.

Nakabo, T. 2002. Fishes of Japan with pictorial keys to the species. 2nd ed. Tokai University Press, Tokyo.

Okiyama, M. 1998. An atlas of the early stage fishes in Japan. Tokai University Press, Tokyo.

Pannella, G. 1971. Fish otoliths: Daily growth layers and periodical patterns. Science (Washington, D.C.) 173:11241127.

Raventós, N., and E. Macpherson. 2001. Planktonic larval duration and settlement marks on the otoliths of Mediterranean littoral fishes. Mar. Biol. (Berl.) 138:1115-1120.

- 2005. Effect of pelagic larval growth and size-at-hatching on post-settlement survivorship in two temperate labrid fish of the genus Symphodus. Mar. Ecol. Prog. Ser. 285:205-211.

Richards, W. J., and K. C. Lindeman. 1987. Recruitment dynamics of reef fishes: Planktonic processes, settlement and demersal ecologies, and fishery analysis. Bull. Mar. Sci. 41:392-410.

Shiogaki, M., and Y. Dotsu. 1973a. The spawning behavior of the tripterygiid blenny, Tripterygion etheostoma. Jpn. J. Ichthyol. 20:36-41 [in Japanese with English abstract].

1973b. The egg development and larval rearing of the tripterygiid blenny, Tripterygion etheostoma. Jpn. J. Ichthyol. 20:42-46 [in Japanese with English abstract].

Thresher, R. E., P. L. Colin, and L. J. Bell. 1989. Planktonic duration, distribution and population structure of western and central Pacific damselfishes (Pomacentridae). Copeia 1989:420-434.

Tyler, J. C., G. D. Johnson, E. B. Brothers, D. M. Tyler, and C. L. Smith. 1993. Comparative early life histories of western Atlantic squirrelfish (Holocentridae): Age and settlement of Rhynchichthys meeki, and juvenile stages. Bull. Mar. Sci. 53:11261150.

Victor, B. C. 1982. Daily otolith increments and recruitment in two coral-reef wrasses, Thalassoma bifasciatum and Halichoeres bivittatus. Mar. Biol. (Berl.) 71:203-208.

. 1986. Duration of the planktonic larval stage of one hundred species of Pacific and Atlantic wrasses (family Labridae). Mar. Biol. (Berl.) 90:317-326.

Victor, B. C., and G. M. Wellington. 2000. Endemism and the pelagic larval duration of reef fishes in the eastern Pacific Ocean. Mar. Ecol. Prog. Ser. 205:241-248.

Wellington, G. M., and B. C. Victor. 1989. Planktonic larval duration of one hundred species of Pacific and Atlantic damselfishes (Pomacentridae). Mar. Biol. (Berl.) 101:557-567.

- 1992. Regional differences in duration of the planktonic larval stage of reef fishes in the eastern Pacific Ocean. Mar. Biol. (Berl.) 113:491-498.

Wilson, D. T., and M. I. McCormick. 1997. Spatial and temporal validation of settlement-marks in the otoliths of tropical reef fishes. Mar. Ecol. Prog. Ser. 153:259271.

- 1999. Microstructure of settlementmarks in the otoliths of tropical reef fishes. Mar. Biol. (Berl.) 134:29-41. 
